\title{
Gendered Production Culture in the German Film Industry
}

\author{
Skadi Loist \\ FILM UNIVERSITY BABELSBERG KONRAD WOLF \\ s.loist [AT] filmuniversitaet.de \\ Elizabeth Prommer ${ }^{1}$ \\ UNIVERSITÄT ROSTOCK \\ elizabeth.prommer [AT] uni-rostock.de
}

\begin{abstract}
German cinema has in recent years experienced a revival of scrutiny for its evident gender inequality. Women directors receive less public funds, work with lower budgets, and their films have smaller releases; however, their films are often more successful artistically and are produced financially more efficiently. The lack of female talent in the industry, thus, can't be a problem of quality as is often argued. Instead, industry structures fail to sustain female directors' careers. This article presents findings from a series of extensive empirical studies on the German film industry. One of the key findings is that the producer is crucial to the gender balance of the team, evidenced by the fact that female producers work significantly more often with female authors and directors.
\end{abstract}

Keywords: Gender Equity, Film Industry, Germany, Gendered Media Production, European Film Industry

\section{Introduction}

As with other national film industries, German cinema has in recent years experienced a revival of scrutiny for its evident gender inequality. Innumerable studies have shown that, despite their apparently progressive image, film industries around the world, including Germany, are decidedly male dominated. ${ }^{2}$ In the United States, women's participation in what are known as "above-the-line" roles are limited to single-figure percentage rates. ${ }^{3}$ And while in Germany rates for women in these positions are in the 20-25 percent range, this still represents a substantial drop from the nearly 50 percent of women graduating from film schools. ${ }^{4}$ 
Discussion about the underrepresentation of women in the film industry in Germany is not new. In the 1970s, activists complained about the low degree of women participating in the film industry and issued a call to action. Forty years ago, in 1979, the association of female film workers ("Verband der Filmarbeiterinnen") was founded. This organization gathered its own statistics and demanded that 50 percent of production funds be allocated to women. ${ }^{5}$ Notwithstanding more recent social change and statutory measures promoting equal treatment and anti-discrimination, little has nominally changed for women in the film industry over the intervening forty years. In the German context, the work by the activist feminist organization Pro Quote Regie (meaning: pro quota directing) has been of key importance in keeping current a discussion about gender equity. Pro Quote Regie was founded in 2014 and in 2017 expanded its scope to examine all creative positions in Pro Quote Film. ${ }^{6}$

Despite these longstanding efforts to identify the manifold forms of bias in the German film industry, the common response of policymakers and key industry figures has been that gender plays no role in the film industry. Instead, it is argued, the only thing that matters is the artistic quality of the films themselves. It is simply a "coincidence" that there is a larger number of male directors, or that "men make more successful films," that "there simply aren't enough good women," and so on. With these industry myths in mind, ${ }^{7}$ we set out to analyze existing, available industry data. Most studies addressing gender inequality in media industries $^{8}$ focus solely on the role of the director, while other creative positions are rarely taken into account..$^{9}$ In the following article, we aim to broaden this scope by addressing creative teams and also examining the role of the producer.

Of the various narratives offered as explanation for the underrepresentation of women in the film industry, we aim to tackle three. First, the belief that there simply aren't enough women. As shown above, this is not true as there are enough female film school graduates, but like in a leaky pipeline, these alumnae do not reach the industry. Second, the idea that in the film industry gender does not matter and it is only the quality of a script or a film that determines merit. Beyond studying the participation of women in film productions, we will also examine what constitutes "success" and "quality" of films, how these are measured, and how this relates to gendered employment in the industry. Third, we will look at the assumption that the employment of women directors (and producers) will imperil a film's chance of financial success. For this, we look at specific funding and distribution structures and propose a method for testing a filmmaker's financial efficiency.

\section{The German Film Industry}

Around 120-140 feature films are produced each year with German majority financing. In Germany, regional and national film funding have a combined yearly budget between 350 and 450 million euros. A film for cinema is usually financed up to 100 percent by a combination of regional and national funds, money from public-broadcasters or private TV stations in combination with a release guarantee from a distributor. If a film is successful at the box office, a proportion of the funding will be paid back to the granting institution. Besides no/ low-budget films, almost all films in the German market have some sort of public subsidy. Therefore, the funding agencies have a great deal of power. Since cinema is seen as both an 
art form of cultural value and an industry, film funding focuses on both aspects with economic funding to support the industry, on one hand, and cultural funding to enhance national culture, on the other.

\section{Capturing the Gender Bias in the Film Industry-Methodology}

Our analysis is based on a data set which represents all German feature films $(\mathrm{N}=687)$ which premiered during the period 2009-2013. The data collected on funding, box office, attendance, and co-production status are sourced from annual reports by the German Federal Film Board (Filmförderungsanstalt [FFA]). In addition, the gender of the director, producer, director of photography (DOP), and scriptwriter was coded. We also collected data on the number of release prints on release date and to measure the success of the festival run by using three major German industry databases online: mediabiz.de of the German trade journal Blickpunkt:Film, and filmportal.de operated by the German Film Institute, and the website by the national film promotion organization German Films. ${ }^{10}$ Here, we recorded whether a film was shown at a specific film festival. We also coded whether the film was nominated for or won a film award.

Based on these data, we compared films directed by women and films directed by men. Here, it is significant to consider that we do not analyze the films only in relation to a total of all films produced in the period, but rather we look at the data of all male-directed films as compared to all female-directed films. We do this so that the two groups can be compared more easily without constantly falling back on the distortion effect due to the small percentage of films by women within the overall production. As the following sections show, these data reveal that films directed and produced by women are subject to gendered gatekeeping throughout the life cycle of a film, starting with casting, through to production financing and distribution.

Our research shows that women are underrepresented as directors, producers, scriptwriters, and cinematographers. While 44 percent of the directing alumni, about 50 percent of the producing and scriptwriting alumni, and 25 percent of cinematography graduates are women, ${ }^{11}$ there is a much wider gender gap in the employment statistics. As little as half of the women graduating from the respective professions are working in the field (see Figure 1).

In the period 2009-2013, women solely directed 22 percent of the films, while no woman was involved at all in 75 percent of the films. In a few rare cases (usually animated films), there were mixed-gender director teams. As producers, women were involved in 41 percent of films, most of the time in a team with a male colleague. Less than one in ten films (9 percent) was produced solely by a woman. There are also very few female-only producing teams. Two-thirds (67 percent) of the screenplays were written by men (alone or in a team of just men); only 14 percent of the scripts are written solely by women. While in cinematography, no women are involved in 87 percent of films, this is also a field of study with the lowest proportion of women.

For the subsequent years, for example, for 2016-2018, the numbers are very similar. The current Diversity Report by the German Federal Association of Directors (Bundesverband Regie $[B V R])$ shows a proportion of female directors of just 22 percent and thus no change in the 


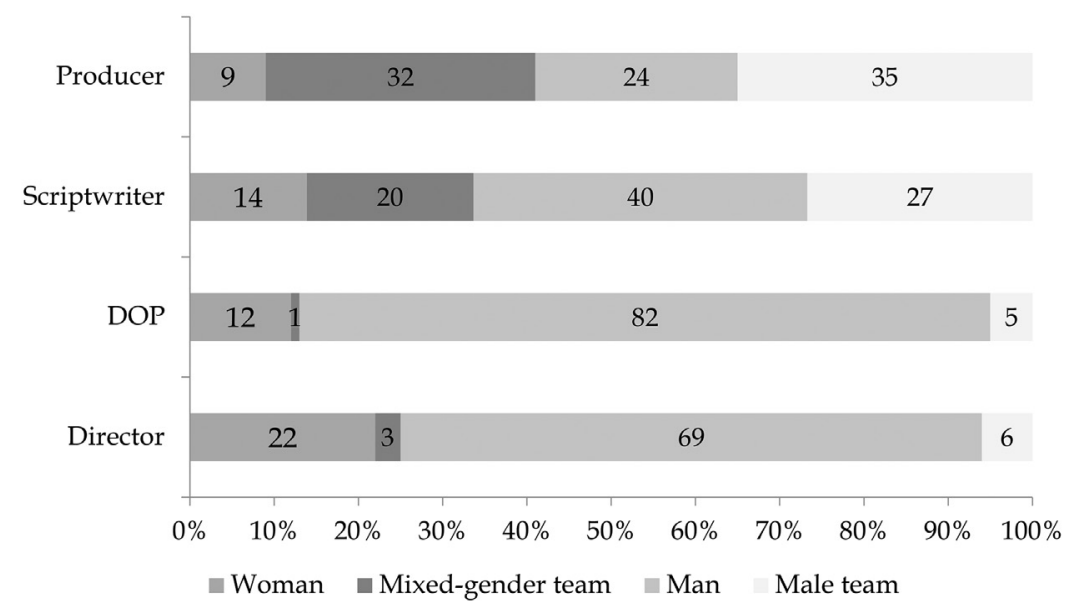

Figure 1. Percentage of women and men working in above-the-line functions for 2009-2013 fictional feature films (co-)produced in Germany. Number of films $(\mathrm{N})=687$.

field of directing. ${ }^{12}$ With regard to scriptwriting (68 percent written solely by men) and production (58 percent produced solely by men), there is also no change. ${ }^{13}$

When looking at the genre of the films directed by women and men it is apparent that women are far more likely to direct a drama. Three out of four films that women direct are categorized by film funder FFA as drama. Only 12 percent of the women-directed films are comedies. While most films directed by men are also dramas (57 percent), they also direct a lot more comedies, which account for one quarter of male-directed films.

Departing from these numbers, we move to further analysis of how gender bias impacts film production in Germany in a way that creates a gendered production culture resulting in the low number of women working in the industry despite the high number of women graduating from film schools.

\section{Correlation between the Gender of Creative Roles, Quality and Economic Success}

The next myth to tackle is the belief that greenlighting and employment practices in the film industry are not the result of gender bias but are based purely on the assessment of film quality. For this, we are taking a cue from the industry logics which measure the value of films against both economic and cultural indicators.

The budgets of theatrically released films are hard to estimate since those numbers are not publicly available in Germany. As a result, we use the same categories as the Diversity Study of the BVR: "LB designates films with a low budget up to two million Euro, MB (medium budget) ranging between two and five million Euro, and HB (high budget) above five million Euro" (Figure 2). ${ }^{14}$ 


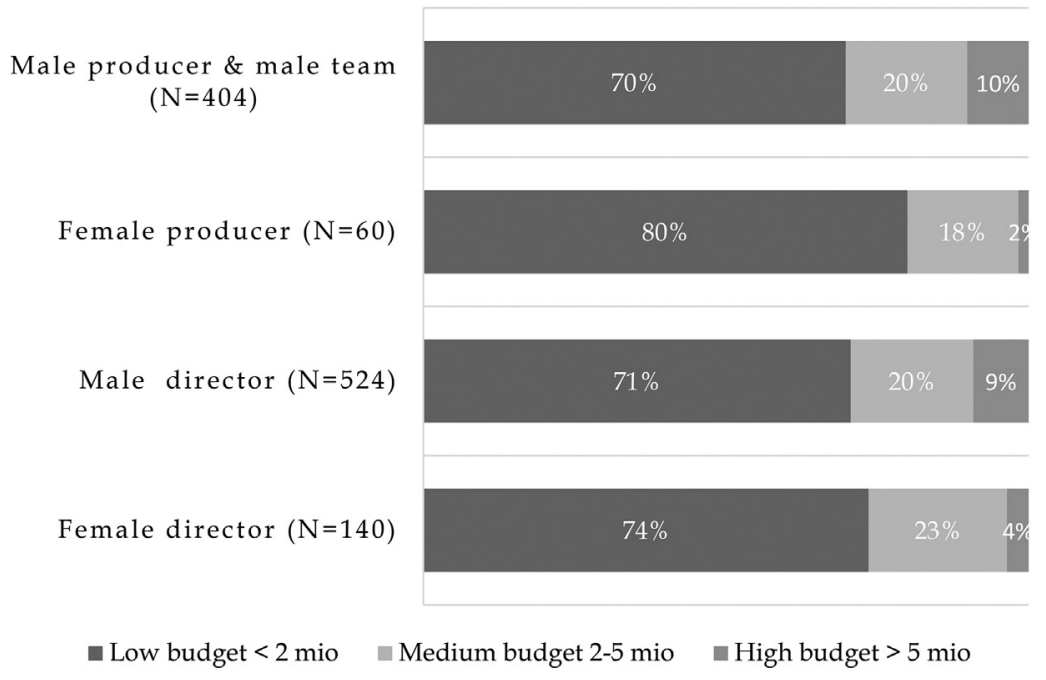

Figure 2. Budget of films in euros by gender. (The percentage refers to the total of all films either directed by women or all films directed by men.)

Only a few films (8 percent), realized either by men or women, have an estimated budget exceeding five million euros. Women are particularly underrepresented in this category. Only 4 percent of all films directed by women have such a budget, while twice as many men (9 percent) are able to work with a high budget. In regard to producers, the difference is even higher: Only 2 percent of female-produced films are in the above five million euros range, but five times as many (10 percent) of the male-produced projects. Accordingly, there is a higher share of women working in the low-budget segment. Women not only direct or produce less movies, in addition they are significantly underrepresented in the high-budget segment.

To finance a film in Germany, there are several film funds available that a producer can apply for; from regional funds to federal funds, funds for development, for production or marketing, funds that give money automatically with a fixed share of the budget, or funds where a jury decides. We looked at the federal production funds which in total amount to about seventy million euros per year by the FFA, with a jury decision; the automatic production fund German Federal Film Fund (Deutscher Filmförderfonds [DFFF], 75 million euros until 2017, 125 million euros as of 2018) annually and the cultural fund of the Federal Government Commissioner for Culture and the Media (Beauftragte der Bundesregierung für Kultur und Medien [BKM]), decided by a jury for non-commercial films. During 2009-2013, men who produced or directed films received on average considerably more money for their films than women (see Figure 3). Considering all paid-out funds, 83 percent of the awarded funds were spent on men. On average, films directed by women received only about 65 percent of the funding that films by men receive.

The DFFF is the funding scheme with the most egregious gender inequality. Womendirected films receive about half of the sum that films directed by men receive, the same is true for producing. The DFFF is an automatic funding scheme that gives money in 


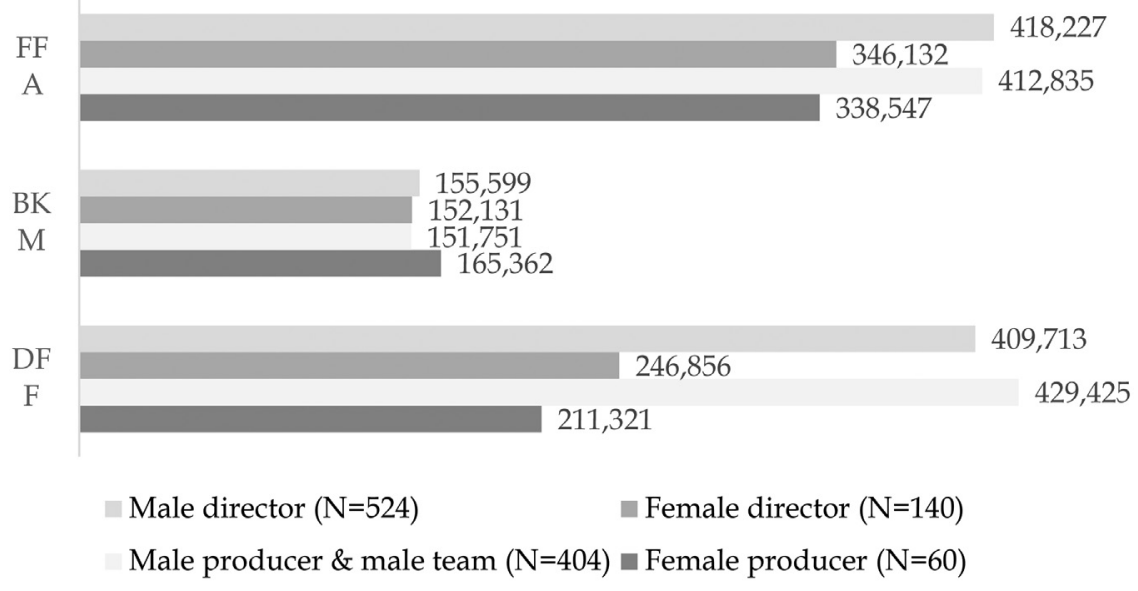

Figure 3. Average federal funding in euros by institution and gender.

proportion to the budget. Here again, we see that women as directors and producers work with smaller budgets and therefore receive smaller funding. This quasi-automatic funding based on budget size clearly disadvantages women. While the amount of funding through the FFA and the BKM do not show great differences, the discrepancy for the DFFF is the most obvious. When considering further gendered positions in the creative team we found that it does not seem to matter who writes the screenplay; however, projects with a male DOP also received funding more often.

In respect to producers, the BKM is again the funding agency with most gender equity. Here, projects with female producers receive more money than projects where no women are involved. Overall, all projects with male producers and production teams receive the most money.

In summary, across all funding schemes, there are fewer women, who then get less funding per film. In aggregate terms, women directors only receive 15 percent of the overall available funding and female producers only receive 5 percent of the overall available sum (see Figure 4).

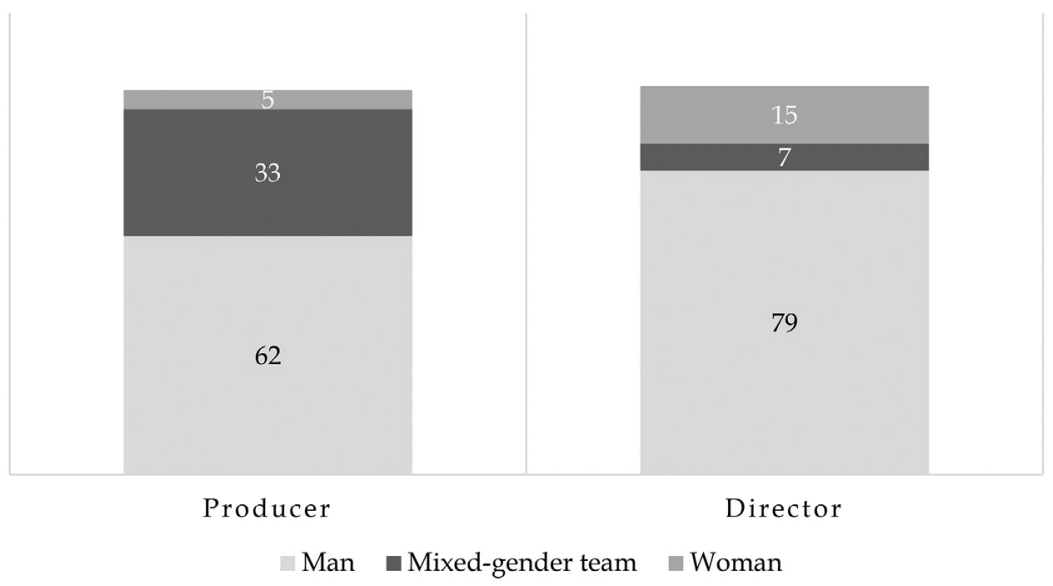

Figure 4. Share of overall federal funding by gender related to producer or director. 


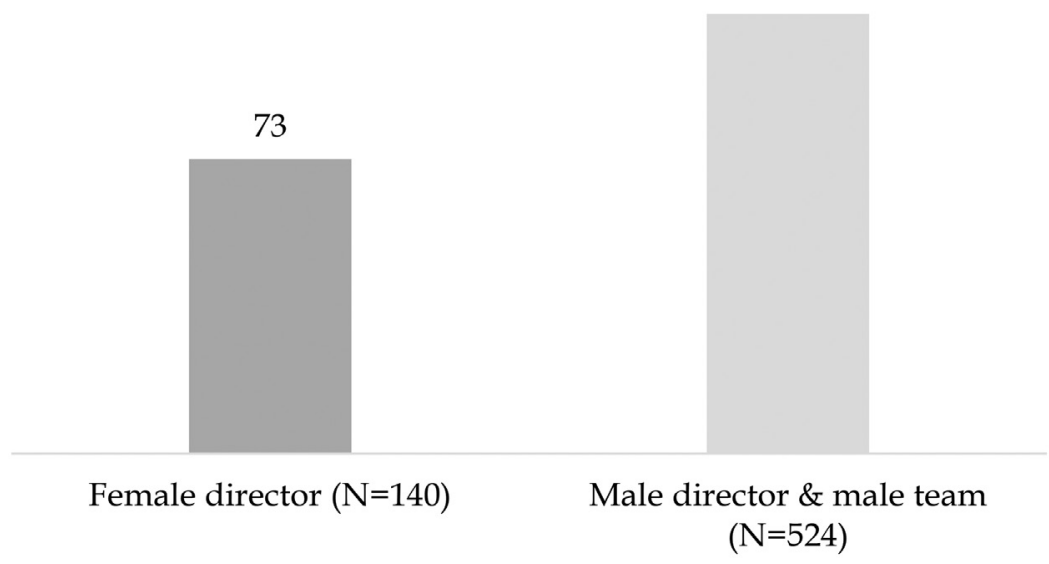

Figure 5. Average number of prints for opening weekend by gender.

Films directed by women do not only have a smaller budget on average, but their films have a smaller release with fewer screens on their opening weekend (Figure 5). Even in the category of low-budget films below two million euros, the amount of prints is significantly smaller than those for films directed by men. Similarly, in the high-budget category, the percentage of prints for women-directed films is lower than for films directed by men. This suggests that the problem is not just that women are perceived as "too risky" for big budgeted productions. They are perceived as too risky for smaller budgeted productions, too. Typically, it is assumed that because women direct films with a smaller budget, they are less able to demonstrate their commercial potential. Our data show that there is a gender gap at the point of distribution and exhibition irrespective of budget size.

Another measure for success applied to films is attendance figures. Again, it is easy to see the gender disparity. Films directed by men have roughly twice as many spectators as films directed by women, which corresponds to twice the amount of box-office intake. However, this measure of economic success is highly influenced by successful outlier films, mostly popular German comedies by well-known comedians, such as Männerherzen (Simon Verhoeven, 2009), Kokowääh (Til Schweiger, 2011), Fack ju Göthe (Bora Dağtekin, 2013), and Der Medicus (Philipp Stölzl, 2013). Not a single woman directed a film that made more than ten million euros at the box office.

Only 35 films had more than one million spectators, in the five years between 2009 and 2013. Out of those only two films were directed by women: Almanya-Willkommen in Deutschland by Yasemin Samdereli (2011) and Wüstenblume by Sherry Hormann (2009).

The 35 exceptional films which had an audience of over one million and a corresponding box-office income of over four million euros are responsible for significant differences in audience and box-office numbers by gender. When taking those outlier films, which only account for 5 percent of all films in the sample, out of the calculation of averages, films directed by men and women only differ slightly in terms of absolute figures of audiences (Figure 6). 


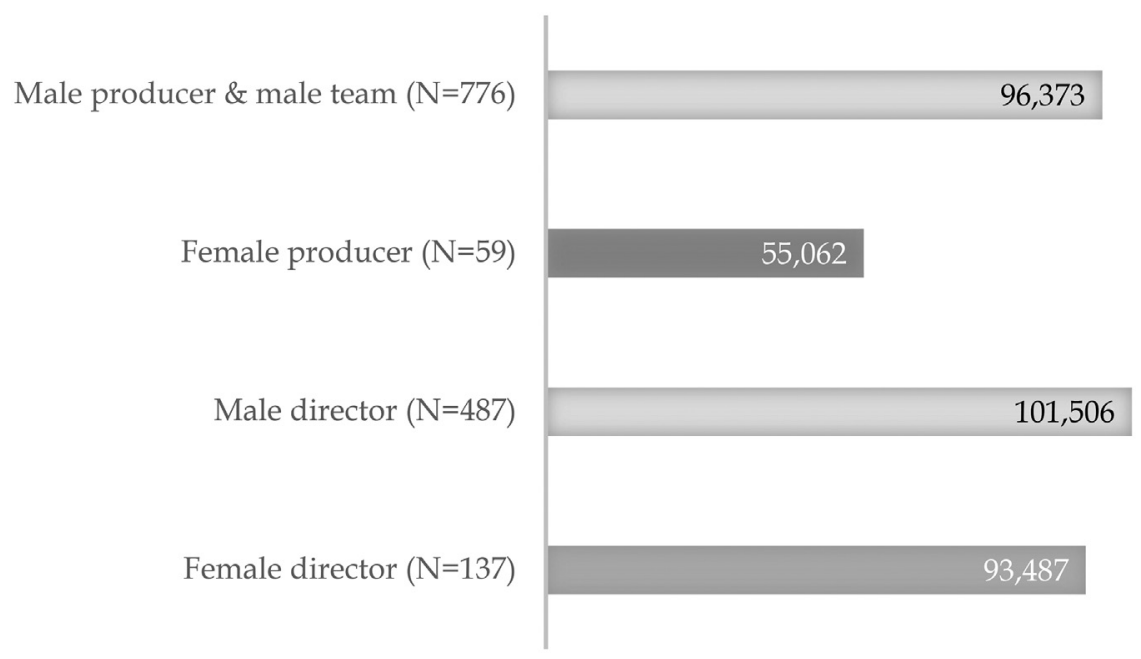

Figure 6. Average number of tickets sold by gender without the outlier top-movies.

\section{Efficiency of Funding}

Women directors and producers have reported the ways in which they are positioned as "risky" by film industry decision makers. ${ }^{15}$ Qualitative interviews in the German film industry have shown how especially the professions of directors and producers are constructed as male, based on the qualities that are ascribed to these positions: enduring, powerful, and assertive.${ }^{16}$ However, another way to look at whether women constitute a risk in the industry is to see how efficiently they use their funding to realize their film projects. We can calculate, for instance, how much subsidy they need to sell one cinema ticket at the box office and compare that to the films made by men. We analyzed all films that were launched in Germany in 2016 which involved mainly German financing with regard to gender of directors, production, scriptwriter, and cinematographer. As data foundation for this analysis, we again referred to the annual reports of the national film funder FFA for 2016 and coded cinema feature films according to gender, funding amounts, and cinema audience figures. ${ }^{17}$

For 2016, 117 films were identified as productions with majority German financing. Of these 117 films, 25 films (21 percent) were directed by a woman, 87 by a man, and 3 in male teams (together 77 percent) and 2 in mixed-gender teams (2 percent). In terms of production, no women were involved in 58 percent of the films, while no women were involved in twothirds of scriptwriting (68 percent), and for 88 percent of the films, no women were involved in cinematography.

The efficiency factor measures how much film funding (in euro) was necessary to sell one cinema ticket. For the calculation, the total funding from FFA and DFFF were added up and divided by the number of cinema visitors for each film. As funding by FFA and DFFF is subject solely to commercial factors, this type of consideration is justified. Regional effects that are required by some regional film funds do not play a role in these national film funding schemes. 
Since film funding is issued on the basis of the individual film, individual films are the basis for our analysis. In order to be able to compare the efficiency of women and men, the average value of the respective individual efficiency factors was determined separately for the respective gender of the creative functions. Calculation followed the formula: Efficiency equals amount of film funding divided by number of cinema visitors. The lower the number the more efficient the film.

This calculation shows that despite having less access to funding, on average, women use these funds more effectively. It emerges that women directors, as well as women producers, are far more efficient in their use of funds. They only need one-third of the amount of funding to attract cinema visitors. Considering combined funding by DFFF and FFA for our sample year 2016, a sold cinema ticket for a male-directed film was subsidized by almost 41 euros compared to 13 euros for a female-directed film. The largest difference occurred with the DFFF (see Table 1). A female director used 7 euros per cinema visitor, while a male director spent almost four times the amount (32 euros). Women directors, therefore, used their money more efficiently multiple times over. Women producers also required less film funding in order to generate one cinema visitor (17 euros for a female producer versus 42 euros for a male producer).

Even in the less commercially driven sector of "artistically ambitious films" that the cultural film fund by the BKM supports, a more efficient use of funds emerges for women in key positions. While the BKM issued 28 percent of its funds in 2016 to films directed by women, these only required 18 euros per cinema ticket sold, compared to 31 euros by a male director (Table 1).

Overall, women use their funds more efficiently. A more nuanced view of commercial success that measures more than gross box-office receipts is necessary for the industry to reconsider its underlying assumptions about "risk."

Table 1. Efficiency Factor 2016: Use of euros from film funds (FFA, DFFF, and BKM in detail) for one cinema ticket sold, according to the gender of the creative functions.

\begin{tabular}{lccc}
\hline Efficiency & FFA & DFFF & BKM \\
\hline Female director $(n=25)$ & 6 & 7 & 18 \\
Male director $(n=90)$ & 16 & 32 & 31 \\
Female producer $(n=10)$ & 6 & 14 & 6 \\
Male producer $(n=67)$ & 17 & 32 & 19 \\
Mixed-gender producer team $(n=39)$ & 10 & 17 & 55 \\
Female scriptwriter $(n=21)$ & 5 & 14 & 3 \\
Male scriptwriter $(n=80)$ & 12 & 28 & 36 \\
\hline
\end{tabular}

Note. FFA $=$ German Federal Film Board DFFF $=$ German Federal Film Fund; BKM = Federal Government Commissioner for Culture and the Media. 


\section{Quality through Artistic Merit}

As discussed earlier, film is considered an artistic as well as a commercial endeavor in the German, and on a larger scale European cinema. Defining a film's success should not only take into account economic measures such as box-office figures, but also data assessing the quality of a film and any other indicators that define artistic success.

Since our study is aiming to counter industry myths with evidence-based arguments using empirical data, we have sought to use quantifiable variables for "quality" rather than drawing on methodologies like discourse analysis to consider critical assessments of "quality" for example. We especially endeavored to find variables that are grounded within an industry logic such as jury-based decisions for awards and festival inclusions which both take into account industry idiosyncrasies but also operate within the legitimizing idea of judged quality. In this context, to get close to a codable and reliable definition of the quality of a film, we analyze whether a film was nominated for or has won an award. We also considered a film festival run as indicating artistic value since either a curator or a jury assess a film's suitability for inclusion. We are aware that these decisions are not objective or transparent, and might indeed be influenced by power structures between sales agents and festivals, for instance. ${ }^{18}$ However, this is also true for the commercial logic of "success." Therefore, we coded all festival participations of a film as they were listed in two major German industry databases, filmportal.de operated by the German Film Institute and the national film promotion organization German Films. We collected the number of festivals the film was screened at and listed a ranking of individual festivals, to account for differences in international A-list festivals or locally relevant festivals. In addition, we coded the number of nominations for film prizes and the actual wins.

Considering these various characteristics, it emerges that German films by women won awards more frequently than German films by men on a pro rata basis. In 2009-2013, 58 percent of films directed by women won a film award or were nominated for an award, while the same applied to 46 percent of films directed by men (Figure 7). Female directors more often win awards when given the chance to make films, at a statistically significant level.

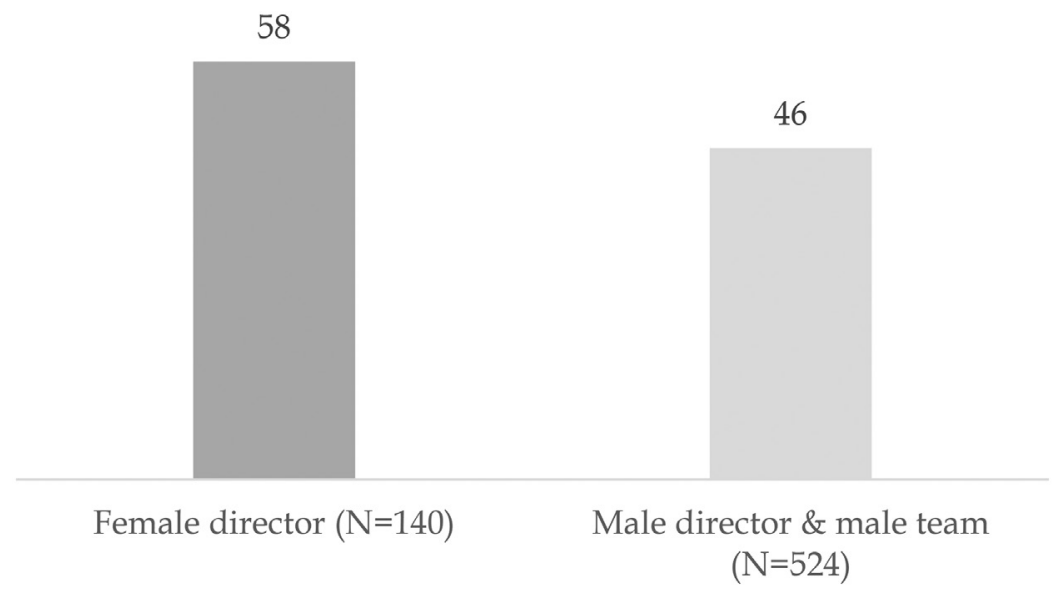

Figure 7. Film awards by gender. (The percentage refers to the total of all films either directed by women or all films directed by men.) 
This success is especially noteworthy when we consider the overall underrepresentation of women in film production, and that their films are usually less well funded. In light of these results, the argument that industry gatekeeping at the point of film funding and crew recruitment is purely based on an assessment of quality is simply not sustainable.

\section{Festival Run}

The basis for the analysis of the festival run is data about festival participation derived from film records available at the German industry platforms filmportal.de, german-films.de, and mediabiz.de, which list screenings at major festivals.

Films directed by women are more often screened at film festivals. More than two thirds (68 percent) of the films in our dataset were shown at festivals. On average, a film directed by a woman is screened at 3.3 festivals, while a film directed by a man is screened at 2.7 festivals. Films directed by women screened at a significantly higher diversity of festivals and with higher international dissemination.

Film festivals traditionally represent a wider range of film productions since their selection process is not based on the commercial potential of a film but the perceived quality and innovation of filmmaking. Here, small low-budget films, arthouse films, and art cinema as well as other thematic films find a platform. ${ }^{19}$ Festivals are especially important for small films with a small marketing budget in order to gain attention and visibility. The selection processes, positive film criticism, and awards at film festivals help films to gain awareness for further commercial exploitation and international distribution. ${ }^{20}$

Within our data between 2009 and 2013, films directed by women have a more successful festival run. More than two thirds of all films were screened at a festival. Half of these went on to further festivals, that is, slightly more than one third (37 percent) of the films screened at two festivals, 20 percent screened at three to four festivals, and only 10 percent screened at six or more festivals. Only 33 films (5 percent) can be seen as festival hits which screened at ten or more festivals.

Films directed by women screened significantly more often at film festivals and were more successful on the festival circuit (see Figure 8). This may be explained by specificities of women-directed films, such as low-budget and genre (drama, children's films), which predestine these films as festival films. Nearly 70 percent of films shown at film festivals are categorized as dramas.

So-called A-list festivals, such as Cannes, Berlin, and Venice, or internationally acclaimed survey festivals, such as Toronto and Vienna, are important platforms for film awareness because of their attached film markets, and high attendance of industry professionals and press. In recent years, discussions have increasingly highlighted and criticized the lack of films directed by women in prestigious competition sections, for example, at the Cannes film festival. ${ }^{21}$ This criticism was met with the argument that there would be an insufficient supply of quality films by women. 


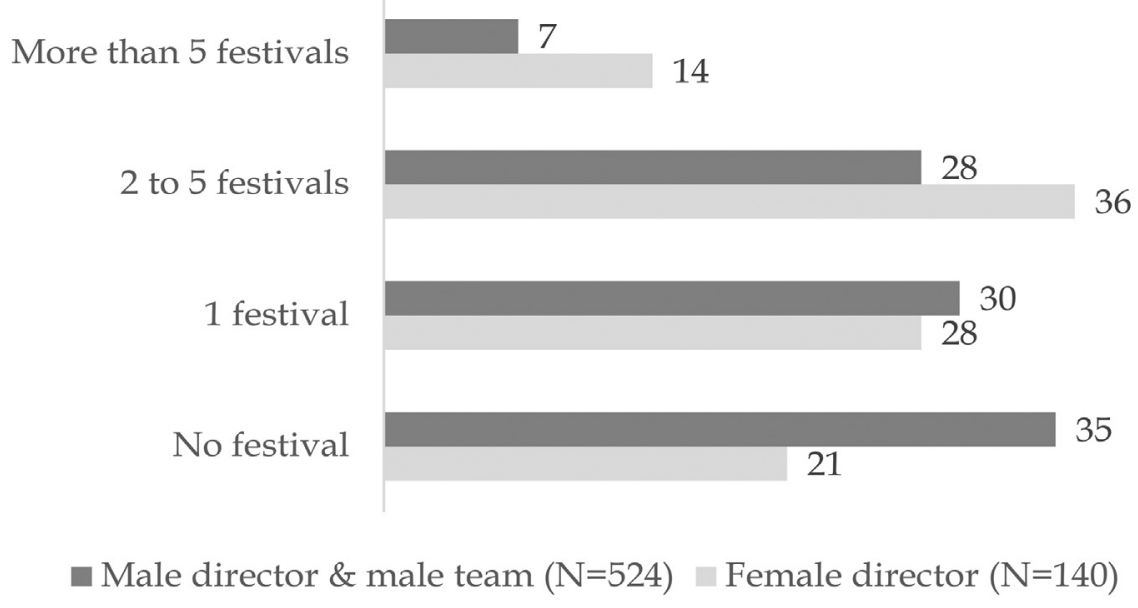

Figure 8. Festival run by gender. (The percentage refers to the total of all films either directed by women or all films directed by men.)

While it is true that there are much fewer films by women available and that submission rates will reflect a lower selection of films by women, there is no reason to assume that there are no quality films by women available for competition selections. Instead, research on film criticism and jury selection shows that unconscious bias works in a way that films by men are favored, on the one hand, because men write more often about male themes and films directed by men and, on the other, juries that are in majority male select films by and about men. ${ }^{22}$ Therefore, bias clearly obscures the view within prestigious festival selection. Our sample shows that when films by women get selected, they are more successful, featuring a longer festival run and more awards won. Hence, the argument that there simply are no quality films by women does not hold.

In light of these findings, several activist feminist film organizations have put pressure on prestigious festivals to reconsider their programming tactics and revisit their biased selection processes and sign the $50: 50$ by 2020 gender parity pledge, which aims for gender monitoring and inclusive programming. ${ }^{23}$ Several prominent festivals, including Germany's two oldest and largest festivals - the Berlin International Film Festival, Berlinale, and DOK Leipzig, the International Leipzig Festival for Documentary and Animated Film-have signed equity pledges and will scrutinize their programming. ${ }^{24}$

\section{The Crucial Role of the Producer}

When we analyze the data of gendered creative positions in relation to each other, the significance of the producer role as key to the occupancy of other creative roles became clear (see Figure 9). When the producer is a woman, the director is more than twice as likely to be a woman (44 percent), compared to a male producer (19 percent). Female producers are 2.5 times more likely to film a screenplay written by a woman (41 percent vs. 16 percent) and cast a woman in 


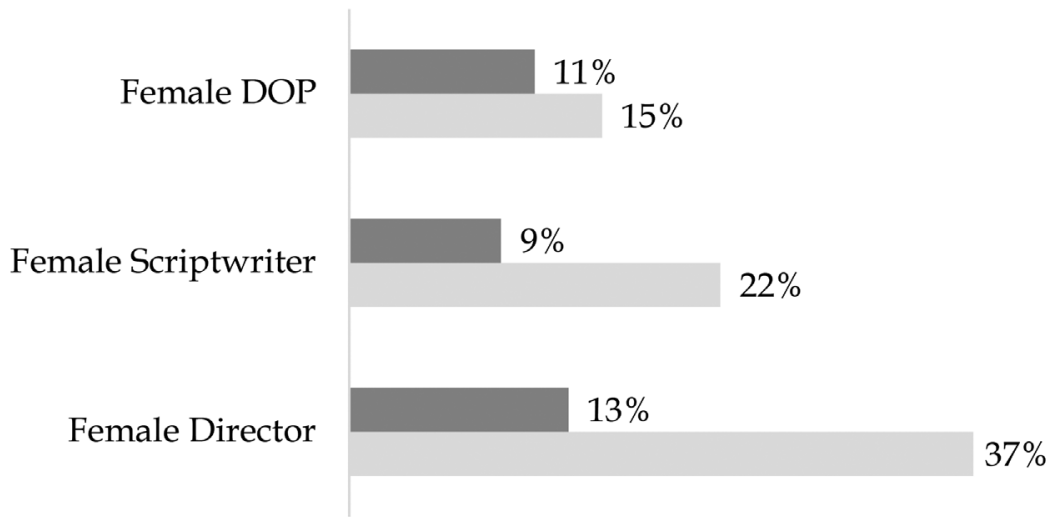

$\square$ Male producer \& male team $(\mathrm{N}=776) \quad$ Female producer $(\mathrm{N}=59)$

Figure 9. The intervening role of the producer shows the influence on the gendered hiring mechanism in further creative team positions.

scenography significantly more frequently. Only the position of the producer shows such strong effects on the filling of creative positions and thus on gendered production culture.

Afemale producer will work with more female directors, who will then work disproportionately with more female cinematographers (18 percent instead of 9 percent). A female director will work with a female screenwriter 10 times (52 percent) as often as a male director. Male directors almost never work with female scripts (4 percent); 83 percent of the scripts that a male director will film are written by men only.

A frequently used argument to explain gender disparity in screen industries is the low level of networking activity by and among women. Often, existing insider relationships and nontransparent decision-making mechanisms are cited as being the greatest barriers according to the qualitative study based on interviews for the FFA report. ${ }^{25}$ In the survey at European level, however, lacking networks are ranked lowest (57 percent) among the elements that deter or prevent female directors. The competitive battle for funding (74 percent), the lack of role models (71 percent) and care work for family members (68 percent) were ranked significantly higher. ${ }^{26}$ This discrepancy is reason enough to take a closer look at the network as a phenomenon.

In Australia, most films are produced and directed by male-dominated networks, as Deb Verhoeven clearly shows in her "Gender offender" analysis. ${ }^{27}$ Through the use of criminal network theory, which was originally developed to intervene in drug cartels, she demonstrates that in Australia, 75 percent of male producers over a ten-year period worked with no women at all or just one single woman in their creative team. She calculated similar values for industry data from Sweden and Germany.

In the German sample, 288 films (42 percent) had no women involved in the three key creative roles: director, producer, and writer. Vice versa only 13 percent of the films had no men involved, that is, men work three times as often only with men. This shows how gendered networks are set up to encourage team building of homogenous groups. 


\section{Conclusion: Moving toward Change in the Industry}

In recent years, various international studies have shown that all areas of the film and television industry are permeated by discriminatory behaviors and structures. Bias begins at the development and scriptwriting stages, and runs through all stages of production, from funding through to implementation for all trades, and is also visible in sales and marketing. There is a pervasive gender bias in a variety of work contexts, and as a result, a "gendering" of the production cultures along stereotypical gendered lines in the creative process. ${ }^{28}$

We contribute this analysis to the wave of studies in different countries that focus on the unequal access by women and men to the film industry. The film industry in Germany shows frameworks and barriers within its industry culture that have a particularly gender-specific impact. For an industry that describes itself as "creative," the dominant practices are shockingly conventional and far from progressive. To date, no gender equality plans have been put forward in Germany specifically for the film and television industry (except for targets announced in the public broadcasting companies with regard to fixed employed staff), despite successful models for change in other European industries.

The most recent report by the Swedish Film Institute (SFI) shows that "gender equality is possible with a systematic approach and that gender equality can be a tool for raising quality." 29 The strategy of the SFI as implemented by CEO Anna Serner demonstrates that a 50 percent participation share of women in cinema films can be achieved with targets. Another successful approach taken by the European co-production fund Eurimage advances equality through the use of a bonus point system. ${ }^{30}$ At Eurimage, not only is the team taken into account, but also the content of the films. ${ }^{31}$ Here, a central factor is not just the promotion of directors, but also of female producers, since they are more likely to work with female directors and scriptwriters and thus make more women visible on screen. The Austrian Film Institute has introduced a "Gender Incentive" system in 2016 in order to promote genderequality change. ${ }^{32}$ The results of the pan-European comparative study initiated by the European Women's Audiovisual network (EWA ${ }^{33}$ have also shown their impact at the political level. In response, recommendations by a committee of ministers of the European Council on "Gender Equality in the Audiovisual Sector" were issued in September 2017, which require European Union (EU) member states to be active in the field. ${ }^{34}$

When it comes to the disbursement of public funds, as is the case with public broadcast television or film funding in Germany and Europe at large, the policy possibilities are wideranging and necessary. And yet, German policymakers are still very reluctant to implement concrete quotas or targets to counter gender inequality in the screen industries. The launch in 2016-2017 of a roundtable by the Minister of State for Culture Monika Grütters, on the topic of "Women in culture and the media" and the many panel discussion hosted by Women in Film and Television (WIFT) Germany and Pro Quote Film indicate a high level of interest and debate. ${ }^{35}$ But it is also clear that discussion alone has not inspired the action necessary for gender equality in the German film industry. We hope that studies such as this will not just add to the debate but will enable research-based policy interventions for overdue, longterm change. 
${ }^{1}$ Skadi Loist is Visiting Professor for Production Cultures in Audiovisual Media Industries at the Film University Babelsberg KONRAD WOLF in Potsdam, Germany, and leads the research project "Film Circulation on the International Film Festival Networkand the Impact on Global Film Culture"(2017-2020). She has published widely on film festivals, queer film culture, gender in media studies, and media industries, and co-edited Film Festivals: History, Theory, Method, Practice (Routledge, 2016). Elizabeth Prommer is Professor and Chair for Communication and Media Studies, Director of the Institute for Media Research at the University of Rostock, Germany. Several of her studies document the underrepresentation of women in audiovisual media, in creative teams and on screen. She conducted field work for Cinema and Gender (2017); Television and Gender (2017) for the German public broadcasters, the Diversity Report 2016 for the German director's guild and the onscreen study Audiovisual Diversity (2017).

${ }^{2}$ See, for instance: Stacy L. Smith, Marc Choueiti, and Katherine Pieper, Inclusion in the Director's Chair? Gender, Race \& Age of Directors across 1.000 Films from 2007-2017 (Los Angeles, CA: USC Annenberg Inclusion Initiative, 2018), http:// assets.uscannenberg.org/docs/inclusion-in-the-directors-chair-2007-2017. pdf; Holly Aylett, "Where Are All the Women Directors? Report on Gender Equality for Directors in the European Film Industry," EWA Women Directors in Film-Comparative Report (EWA, 2016); Katharina Hochfeld, Karen Genz, Vivien Iffländer, and Elizabeth Prommer, Gender und Film: Rahmenbedingungen und Ursachen der Geschlechterverteilung von Filmschaffenden in Schlüsselpositionen in Deutschland (Berlin: FFA-Filmförderungsanstalt, 2017), http://www.ffa.de/ download.php?f=f9bdfb3d80d453df802d858a18c0079a\&target=0; Bundesverband Regie, Vierter Regie-Diversitätsbericht des BVR für das Jahr 2016: Genderanalyse zur Regievergabepraxis in deutschen fiktionalen Primetime-Programmen von ARD, ZDF, RTL, SAT.1 und VOX sowie im deutschen Kinospielfilmen (Berlin: Bundesverband Regie, 2017).

${ }^{3}$ Laura Grindstaff, "Business as Usual, American Style: Reality TV and the Gendered Politics of 'Women's Work," in Gender-Medien-Screens: (De)Konstruktionen aus wissenschaftlicher und künstlerischer Perspektive, ed. Elizabeth Prommer, Martina Schuegraf, and Claudia Wegener (Konstanz: UVK, 2015), 183-197.

${ }^{4}$ Hochfeld et al., Gender und Film, 25.

${ }^{5}$ Verband der Filmarbeiterinnen e.V. "Manifest der Filmarbeiterinnen," Frauen und Film, no. 22 (1979): 27.

${ }^{6}$ For further context about the current German situation see Sebastian Heiduschke, "Women's Interventions in the Contemporary German Film Industry," Camera Obscura: Feminism, Culture, and Media Studies 33 (3, 2018): 147-55.

${ }^{7}$ See a condensed collection of these industry myths in Skadi Loist, "Gendered Media Industries: Argumente für eine geschlechtergerechte und diverse Filmindustrie," Navigationen 18 (2, 2018): 135-58, and Anna Serner, "Der schwedische Weg: 'Genug geredet-jetzt ist Zeit zu handeln," TelevIZIon 30 (2, 2017): 66-68.

${ }^{8}$ See, for instance: Smith, Choueiti, and Pieper, Inclusion in the Director's Chair?; Aylett, "Where Are All the Women Directors?; Bundesverband Regie, Vierter RegieDiversitätsbericht des BVR für das Jahr 2016. 
${ }^{9}$ Among the exceptions are the reports of the German and Austrian film funding agencies, which added further departments in the monitoring process: Hochfeld et al., Gender und Film; Eva Flicker and Lena L. Vogelmann, "Österreichischer Film Gender Report 2012-2016: Zentrale Ergebnisse" (Wien, 2018), https://equal ity.filminstitut.at/de/view/files/download/forceDownload/?tool=12\&feld= download\&sprach_connect=91\&tmp=true.

${ }^{10}$ We would like to thank Heike Hausmann, Julia Natusch, Pauline Raabe, and Tina Rudolf for support in the coding process.

${ }^{11}$ Hochfeld et al., Gender und Film, 25.

${ }^{12}$ Bundesverband Regie, Vierter Regie-Diversitätsbericht des BVR für das Jahr 2016, 6.

${ }^{13}$ Hochfeld et al., Gender und Film.

${ }^{14}$ Bundesverband Regie, Erster Regie-Diversitätsbericht des BVR 2010-2013, 35.

${ }^{15}$ Aylett, "Where Are All the Women Directors?" 44.

${ }^{16}$ Hochfeld et al., Gender und Film, 44-46.

${ }^{17}$ FFA Info 1: Zahlen aus der Filmwirtschaft (Berlin: FFA-Filmförderungsanstalt, 2017).

${ }^{18}$ See, for instance, Mark Persanson's discussion of sales agents and their influence on festival programming: Peranson, Mark. "First You Get the Power, Then You Get the Money: Two Models of Film Festivals," Cineaste 33 (3, 2008): 37-43.

${ }^{19}$ Cf. Skadi Loist. "Crossover Dreams: Global Circulation of Queer Film on the Film Festival Circuits," Diogenes 62 (1, 2015): 57-72.

${ }^{20}$ For a study evidencing the effect of festival awards on a film's exploitation see Stephen Mezias, Jesper Strandgaard Pedersen, Ji-Hyun Kim, Silviya Svejenova, and Carmelo Mazza, "Transforming Film Product Identities: The Status Effects of European Premier Film Festivals, 1996-2005," in Negotiating Values in the Creative Industries: Fairs, Festivals and Competitive Events, ed. Brian Moeran and Jesper Strandgaard Pedersen (Cambridge: Cambridge University Press, 2011), 169-96.

${ }^{21}$ See, for instance La Barbe, "Men of the Cannes Film Festival, Keep Defending those Masculine Values," The Guardian, May 15, 2012, http://www.theguard ian.com/commentisfree/2012/may/15/cannes-film-festival-men-open-letter and Nick Vivarelli, "Women's Groups Blast Venice Film Festival for Lack of Female Representation," Variety, August 10, 2018. https://variety.com/2018/film/news/ venice-film-festival-under-fire-women-directors-1202901723/.

${ }^{22}$ Regarding gendered film criticism see Martha M. Lauzen "Thumbs Down 2018: Film Critics and Gender, and Why It Matters," San Diego, CA, 2018. https://womenintvfilm.sdsu.edu/wp-content/uploads/2018/07/2018_Thumbs_Down_Report.pdf and regarding the influence of gendered commissions see Hochfeld et al., Gender und Film, 47-48, for the influence of gendered selection committee at festivals see Tanja C. Krainhöfer and Konrad Schreiber, "Women Show Their Faces-Men, Their Films! Study on the Representation of Film Works by Women in Germany's Festival Program," transl. Geraldine Blecker, Filmfestival-Studien.de, 2016, http://www. filmfestival-studien.de/wp-content/uploads/20-05-16-Gender-Study-GermanFilm-Festivals-2016_E.pdf.

${ }^{23}$ Women and Hollywood, "Festivals That Have Committed to the Gender Parity Pledge," February 10, 2019, https://womenandhollywood.com/resources/ 
festivals-that-have-committed-to-the-gender-parity-pledge / (accessed February 10, 2019).

${ }^{24} \mathrm{Cf}$. The Gender Evaluation of Berlinale 2019 and the press release of DOK Leipzig: "Gender Evaluation: Berlinale 2019," Internationale Filmfestspiele Berlin, Berlin, January 29, 2019. https://www.berlinale.de/media/pdf_word/pd/69_ifb_1/69_ IFB_Gender_Evaluation.pdf; DOK Leipzig, "DOK Leipzig Sets Quota for Female Directors in German Competition: Selection Committee for 2018 Predominantly Composed of Women," news release, May 23, 2018, https://www.dok-leipzig.de/ dok/presse/pressemitteilungen/2018/032018/content_item_49845/Press_ Release03_DOK_Leipzig_sets_Quota_for_Female_Directors_in_German_ Competition.pdf (accessed August 13, 2018).

${ }^{25}$ Hochfeld et al., Gender und Film, 55-57.

${ }^{26}$ Aylett, "Where Are All the Women Directors?" 47-50.

${ }^{27}$ Deb Verhoeven and Stuart Palmer, "Women Aren't the Problem in the Film Industry, Men Are," The Conversation, November 15, 2016, http://theconversation.com/ women-arent-the-problem-in-the-film-industry-men-are-68740; Deb Verhoeven, "The 'Gender Offender' Analysis: How and Why We Did It (Part One)," http://kinomatics.com/the-gender-offender-analysis-how-and-why-we-did-it-part-one/; Deb Verhoeven, "The 'Gender Offender' Analysis: How and Why We Did It (Part Two)," http://kinomatics.com/the-gender-offender-analysis-how-and-why-wedid-it-part-two/.

${ }^{28}$ See Miranda J. Banks, "Gender Below-the-Line: Defining Feminist Production Studies," in Production Studies: Cultural Studies of Media Industries, ed. Vicki Mayer, Miranda J. Banks, and John T. Caldwell (NY: Routledge, 2009), 87.

${ }^{29}$ Jenny Wikstrand, "The History and Future of Gender Equality in Swedish Film," in EFARN Research Highlights 2018: A Selection of Research by European Film Agencies, ed. Patrizia Simone (Strasbourg: European Audiovisual Observatory, 2018), 84. See also the full report: Jenny Wikstrand, "The Money Issue: Gender Equality Report" (Stockholm: Swedish Film Institute, 2018), https://www.filminstitutet.se/globalassets /_dokument/sfi-gender-equality-report-2018---lowres.pdf.

${ }^{30}$ Melanie Goodfellow, "Film Industry Gender Equality 'Bad but Getting Better' Says Berlinale Conference," Screen Daily, February 10, 2019, https://www.screendaily. com/news /-film-industry-gender-equality-bad-but-getting-better-says-berl inale-conference/5136780.article?referrer = RSS (accessed February 27, 2019).

${ }^{31}$ Isabel Castro Martinez, "Why Gender Equality Matters to Eurimages, the European Film Co-Production Fund," European Journal of Women's Studies 23 (4, 2016): 440-46.

${ }^{32}$ See https://equality.filminstitut.at/en/what-happended-so-far /.

${ }^{33}$ Aylett, "Where Are All the Women Directors?"

${ }^{34}$ Recommendation CM/Rec(2017)9 of the Committee of Ministers to member States on gender equalityin the audiovisual sector, Council of Europe, September 27,2017, https:// search.coe.int/cm/Pages/result_details.aspx?ObjectID=090000 $16807509 \mathrm{e} 6$.

${ }^{35}$ Gabriele Schulz, Carolin Ries, and Olaf Zimmermann, Frauen in Kultur und Medien: Ein Überblick über aktuelle Tendenzen, Entwicklungen und Lösungsvorschläge (Berlin: Deutscher Kulturrat, 2016). 


\section{ORCID iD}

Skadi Loist (1D https://orcid.org/0000-0002-8299-4103

\section{Bibliography}

Aylett, Holly. "Where Are All the Women Directors? Report on Gender Equality for Directors in the European Film Industry." EWA Women Directors in Film-Comparative Report, European Women's Audiovisual Network (EWA), 2016.

Banks, Miranda J. "Gender Below-the-Line: Defining Feminist Production Studies." In Production Studies: Cultural Studies of Media Industries, edited by Vicki Mayer, Miranda J. Banks and John T. Caldwell, 87-98. New York: Routledge, 2009.

Bundesverband Regie. Erster Regie-Diversitätsbericht des BVR 2010-2013: Analysen zur Regievergabepraxis in den fiktionalen Primetime-Programmen von ARD und ZDF sowie Genderreport zum deutschen Kinofilm. Berlin: Bundesverband Regie, 2014. http:// cb-tm.de/notiz/download.php?id=101508.

Bundesverband Regie. Zweiter Regie-Diversitätsbericht des BVR 2014: Analyse von Genderund Altersstruktur der Regie in den fiktionalen Primetime-Programmen von ARD und ZDF sowie beim deutschen Kinospielfilm. Berlin: Bundesverband Regie, 2015-16. http://cb-tm.de/notiz/download.php?id=101508.

Bundesverband Regie. Dritter Regie-Diversitätsbericht des BVR 2015: Gender-Analyse zur Regievergabepraxis in den fiktionalen Primetime-Programmen von ARD, ZDF, RTL, SAT.1 und VOX sowie im deutschen Kinospielfilm. Berlin: Bundesverband Regie, 2016. https:// www.regieverband.de/files/downloads/3_Regie-Diversitaetsbericht_2016_online. pdf.

Bundesverband Regie.Vierter Regie-Diversitätsberichtdes BVRfürdas Jahr2016: Genderanalyse zur Regievergabepraxis in deutschen fiktionalen Primetime-Programmen von ARD, ZDF, RTL, SAT.1 und VOX sowie im deutschen Kinospielfilmen. Berlin: Bundesverband Regie, 2017.

Castro Martinez, Isabel. "Why Gender Equality Matters to Eurimages, the European Film Co-Production Fund." European Journal of Women's Studies 23, no. 4 (2016): 440-46. doi:10.1177/1350506816666220.

Council of Europe. Recommendation CM/Rec(2017)9 of the Committee of Ministers to member States on gender equality in the audiovisual sector. September 27, 2017. https:// search.coe.int/cm/Pages/result_details.aspx?ObjectID=09000016807509e6.

DOK Leipzig. "DOK Leipzig Sets Quota for Female Directors in German Competition: Selection Committee for 2018 Predominantly Composed of Women." Press release, May 23, 2018. https://www.dok-leipzig.de/dok/presse/pressemitteilungen/2018/032018/ 
content_item_49845/Press_Release03_DOK_Leipzig_sets_Quota_for_Female_ Directors_in_German_Competition.pdf (accessed August 13, 2018).

"FFA Info 1: Zahlen aus der Filmwirtschaft." FFA-Filmförderungsanstalt, Berlin, 2017.

Flicker, Eva, and Lena L. Vogelmann. "Österreichischer Film Gender Report 2012-2016:Zentrale Ergebnisse." Wien, 2018. https://equality.filminstitut.at/de/view/files/download/ forceDownload $/$ ?tool=12\&feld=download\&sprach_connect=91\&tmp=true.

"Gender Evaluation: Berlinale 2019." Internationale Filmfestspiele Berlin, Berlin, January 29, 2019. https://www.berlinale.de/media/pdf_word/pd/69_ifb_1/69_IFB_ Gender_Evaluation.pdf.

Goodfellow, Melanie. "Film Industry Gender Equality 'Bad But Getting Better' Says Berlinale Conference." Screen Daily, February 10, 2019. https://www.screendaily.com/ news /-film-industry-gender-equality-bad-but-getting-better-says-berlinale-con ference/5136780.article?referrer=RSS (accessed February 27, 2019).

Grindstaff, Laura. "Business as Usual, American Style: Reality TV and the Gendered Politics of 'Women's Work." In Gender-Medien-Screens: (De)Konstruktionen aus wissenschaftlicher und künstlerischer Perspektive, edited by Elizabeth Prommer, Martina Schuegraf and Claudia Wegener, 183-97. Alltag, Medien und Kultur 13. Konstanz: UVK, 2015.

Heiduschke, Sebastian. "Women's Interventions in the Contemporary German Film Industry." Camera Obscura: Feminism, Culture, and Media Studies 33, no. 3 (2018): 147-55. doi:10.1215/02705346-7142224.

Hochfeld, Katharina, Karen Genz, Vivien Iffländer, and Elizabeth Prommer. Gender und Film: Rahmenbedingungen und Ursachen der Geschlechterverteilung von Filmschaffenden in Schlüsselpositionen in Deutschland. Berlin: FFA-Filmförderungsanstalt, 2017. http:// www.ffa.de/download.php?f=f9bdfb3d80d453df802d858a18c0079a\&target=0.

Jenke, Marion. Berufswege von Alumni einer Filmhochschule: Arbeitsmarktsituation und Spezifika des Studiums. Wiesbaden: Springer VS, 2013.

Jenke, Marion. "Weibliche Karrieren: Absolventinnen der HFF 'Konrad Wolf' und ihre berufliche Situation." In Gender-Medien-Screens: (De)Konstruktionen aus wissenschaftlicher und künstlerischer Perspektive, edited by Elizabeth Prommer, Martina Schuegraf, and Claudia Wegener, 149-60. Alltag, Medien und Kultur 13. Konstanz: UVK, 2015.

Krainhöfer, Tanja C., and Konrad Schreiber. "Women Show Their Faces-Men, Their Films! Study on the Representation of Film Works by Women in Germany's Festival Program." Translated by Geraldine Blecker, Filmfestival-Studien.de, 2016. http://www.filmfestival-studien.de/ wp-content/uploads/20-05-16-Gender-Study-German-Film-Festivals-2016_E.pdf.

La Barbe. "Men of the Cannes Film Festival, Keep Defending those Masculine Values." The Guardian, May 15, 2012. http://www.theguardian.com/commentisfree/2012/ may/15/cannes-film-festival-men-open-letter.

Lauzen, Martha M. “Thumbs Down2018:Film Criticsand Gender, andWhy It Matters."San Diego, CA, 2018. https://womenintvfilm.sdsu.edu/wp-content/uploads/2018/07/2018_ Thumbs_Down_Report.pdf. 
Loist, Skadi. "Crossover Dreams: Global Circulation of Queer Film on the Film Festival Circuits." Diogenes 62, no. 1 (2015): 57-72. doi:10.1177/0392192116667014.

Loist, Skadi. "Gendered Media Industries: Argumente für eine geschlechtergerechte und diverse Filmindustrie." Navigationen 18, no. 2 (2018): 135-58.

Mezias, Stephen, Jesper Strandgaard Pedersen, Ji-Hyun Kim, Silviya Svejenova, and Carmelo Mazza. "Transforming Film Product Identities: The Status Effects of European Premier Film Festivals, 1996-2005." In Negotiating Values in the Creative Industries: Fairs, Festivals and Competitive Events, edited by Brian Moeran and Jesper Strandgaard Pedersen, 169-96. Cambridge: Cambridge University Press, 2011.

Peranson, Mark. "First You Get the Power, Then You Get the Money: Two Models of Film Festivals." Cineaste 33, no. 3 (2008): 37-43.

Prommer, Elizabeth. "Effizienz in der Filmförderung des Bundes nach Geschlecht." Universität Rostock, Rostock, 2018.

Prommer, Elizabeth, and Skadi Loist. "Who Directs German Feature Films? Gender Report: 2009-2013." Institut für Medienforschung, Universität Rostock, Rostock, 2015. https://www.imf.uni-rostock.de/forschung/kommunikations-und-medienwissenschaft/gender-bericht/.

Prommer, Elizabeth, and Skadi Loist. "Where are the Women Directors? National ReportGermany." European Women's Audiovisual Network (EWA), 2016.

Schulz, Gabriele, Carolin Ries, and OlafZimmermann. Frauen in Kultur und Medien: Ein Überblick über aktuelle Tendenzen, Entwicklungen und Lösungsvorschläge. With the assistance of Monika Grütters and Christian Höppner. Berlin: Deutscher Kulturrat, 2016.

Serner, Anna. "Der schwedische Weg: 'Genug geredet-jetzt ist Zeit zu handeln." TelevIZIon 30, no. 2 (2017): 66-68.

Slansky, Peter C. Filmhochschulen in Deutschland: Geschichte, Typologie, Architektur. München: Ed. Text + Kritik, 2011.

Smith, Stacy L., Marc Choueiti, and Katherine Pieper. "Inclusion in the Director's Chair? Gender, Race \& Age of Directors across 1.000 Films form 2007-2017." USC Annenberg Inclusion Initiative, Los Angeles, CA, 2018. http://assets.uscannenberg.org/docs/ inclusion-in-the-directors-chair-2007-2017.pdf.

Spitzenorganisation der Filmwirtschaft. "Filmstatistisches Jahrbuch 2017." Baden-Baden, 2017.

Verband der Filmarbeiterinnen e.V. "Manifest der Filmarbeiterinnen." Frauen und Film, no. 22 (1979): 27.

Verhoeven, Deb. "The 'Gender Offender' Analysis: How and Why We Did It (Part One)." http://kinomatics.com/the-gender-offender-analysis-how-and-why-we-did-itpart-one/ (accessed April 11, 2018).

Verhoeven, Deb. "The 'Gender Offender' Analysis: How and Why We Did It (Part Two)." http://kinomatics.com/the-gender-offender-analysis-how-and-why-we-did-itpart-two/ (accessed April 11, 2018). 
Verhoeven, Deb, and Stuart Palmer. "Women Aren't the Problem in the Film Industry, Men Are." The Conversation, November 15, 2016. http://theconversation.com/womenarent-the-problem-in-the-film-industry-men-are-68740.

Vivarelli, Nick. "Women's Groups Blast Venice Film Festival for Lack of Female Representation." Variety, August 10, 2018. https://variety.com/2018/film/news/venice-filmfestival-under-fire-women-directors-1202901723/.

Wikstrand, Jenny. "The History and Future of Gender Equality in Swedish Film." In EFARN Research Highlights 2018: A Selection of Research by European Film Agencies, edited by Patrizia Simone, 84-88. Strasbourg: European Audiovisual Network, 2018. https:// rm.coe.int/efarn-research-highlights-2018/16808ee5c7 (accessed February 27, 2019).

Wikstrand, Jenny. "The Money Issue: Gender Equality Report 2018." Swedish Film Institute, Stockholm, 2018. https://www.filminstitutet.se/globalassets/_dokument/sfi-gen der-equality-report-2018---lowres.pdf.

Women and Hollywood. "Festivals That Have Committed to the Gender Parity Pledge." February 10, 2019. https://womenandhollywood.com/resources/festivals-thathave-committed-to-the-gender-parity-pledge/. 
